\title{
Inisiasi Ketangguhan Masyarakat dalam Mengatasi Adiksi NAPZA: Menelaah Program Rehabilitasi
}

\author{
Initiation of Community Resilience on Drug Addiction: Exploring \\ Rehabititation Programs
}

\author{
Maria Goretti Adiyanti \\ Fakultas Psikologi Universitas Gadjah Mada ${ }^{1}$
}

\begin{abstract}
The problem of drug abuse and addiction cannot yet be resolved completely even though many addicts have done rehabilitation. This paper aims to analize intervention programs for drug addicts and propose alternative programs that emphasize psychological aspects. This paper begins by interpreting the implementation of the Drug Rehabilitation Center Practice and relaps after the addict completes rehabilitation. An understanding of addiction is needed to provide an understanding of the mental state of addicts and the process of change that must be experienced during the rehabilitation process. The recovery process through the Rehabilitation Institution will be discussed, especially in achieving "clean and sober" conditions. At the end of the article an alternative of psychological growth program is presented as a complementary program with the exsisting TC program. Psychological growth programs are expected to have a contribution to overcome psychological problems that until now have not been addressed comprehensively.
\end{abstract}

Keywords: addiction rehabilitation method; psychological growth; program alternative

\begin{abstract}
Abstrak. Masalah penyalahgunaan dan kecanduan napza masih menjadi masalah besar yang belum dapat teratasi dengan tuntas walaupun telah banyak pecandu yang mengikuti rehabilitasi. Tulisan ini bertujuan menelaah program intervensi untuk pecandu napza dan memberikan alternatif program yang menekankan pada aspek psikologis. Tulisan diawali dengan pemaknaan kondisi lapangan dalam hal program yang dilaksanakan di Panti Rehabilitasi Napza dan beberapa data tentang relaps setelah beberapa pecandu mengikuti proses rehabiltasi. Pemahaman tentang kecanduan diperlukan untuk memberikan gambaran tentang kondisi mental para pecandu dan proses perubahan yang harus dialami selama melakukan proses rehabilitasi. Proses pemulihan melalui Panti Rehabilitasi menjadi pilihan untuk dibahas terutama dalam mencapai mantan pecandu yang benar-benar "bersih dan waras" Di akhir tulisan disampaikan alternative program pertumbuhan psikologis dalam TC sebagai program komplementer dengan program TC yang telah dijalankan. Program pertumbuhan psikologis diharapkan dapat membantu mengatasi masalah-masalah psikologis yang sampai dengan saat ini belum teratasi secara komprehensif.
\end{abstract}

Kata kunci: alternatif program; metode rehabilitasi adiksi; psychological growth

\footnotetext{
${ }^{1}$ Korespondensi mengenai artikel ini dapat melalui: adiyanti_psy@ugm.ac.id;
} 


\section{Pengantar}

\section{Dari Pengalaman Lapangan}

Saat ini di Indonesia telah banyak dijumpai banyak panti rehabilitasi untuk pencandu Napza, baik yang dikelola oleh pemerintah maupun swasta. Penelusuran menggunakan internet terhadap 15 pusat rehabilitasi di beberapa daerah di Indonesia disertai dengan wawancara mendalam terhadap 18 orang kepala panti atau yang mewakili, ada 5 metode program yang dilakukan yaitu: Therapeutic Community (TC), pendekatan agama, komunitas, medis, serta 12 tradisi dan 12 langkah. Dari 5 metode tersebut, metode yang paling terstruktur dan banyak diterapkan adalah TC. Pada metode terapi yang ditelusur, durasi perawatan paling pendek adalah 2 minggu dan paling panjang 1 tahun. Pada umumnya penanganan masalah-masalah psikologis yang mendasari munculnya adiksi belum sepenuhnya tertangani, terbukti ada mantan pecandu yang telah keluar dari rehabilitasi tetapi masih menyatakan mempunyai masalah dengan orang tua, dengan dirinya sendiri dan menyatakan belum mampu mengatasi pengaruh lingkungan (Adiyanti, Yuniarti, \& Yana, 2014). Jika proses rehabilitasi dievaluasi dengan transteoritical, tampak bahwa tahapan yang paling banyak dicapai adalah kontemplasi (Adiyanti \& Yuniarti, 2015). Pada tahap ini residen pecandu telah mempunyai kesadaran untuk berubah dengan kekuatan diri tetapi belum mempunyai perencanaan untuk perubahan yang akan dilakukan, apalagi menuangkan rencana tersebut dalam tindakan nyata. Artinya para residen pecandu yang telah mengikuti proses rehabilitasi masih memerlukan pengolahan aspek psikologi yang menjadi dasar munculnya kecanduan.
Hasil penelusuran tentang keberhasilan keikutsertaan program rehabilitasi menunjukkan bahwa sekitar $35 \%$ penyalahguna yang mengikuti kegiatan rehabilitasi di satu panti yang menggunakan metode Naroctics Anonymous (NA) bisa pulih (Fajriah, Husaini, \& Adenan, 2016). Hal ini berarti masih ada 65\% yang statusnya tidak dilaporkan sebagai pulih. Data di Rumah Sakit Ketergantungan Obat (RSKO) pada 2013 sebagian besar (65,17\%) pasien rawat jalan dan rawat inap penyalahguna narkoba adalah pasien dengan status pengguna lama narkoba (Primadi, 2014). Tingginya angka relaps, mengharuskan adanya aktivitas after care bagi pecandu yang telah mengikuti proses rehabilitasi untuk mempertahankan kebersihan dan meningkatkan kewarasan dan kesehatan mentalnya. Namun demikian, dari 15 panti yang ditelusur proses rehabilitasinya, baru dua panti yang telah menaruh perhatian pada tahapan yang paling banyak after care.

Kondisi tersebut menumbuhkan ide munculnya tulisan ini. Orientasi pembahasan akan difokuskan pada metode yang digunakan dalam proses rehabilitasi.

\section{Pembahasan}

Dari Pengguna ke Adiksi: Faktor Pribadi, Keluarga, dan Lingkungan

Gott \& Hetzel-Riggin, (2018) menyimpulkan dari berbagai acuan dan hasil penelitian bahwa dalam diri individu ada dua bentuk sistem perilaku, yaitu sistem penghambat perilaku dan sistem aktivasi perilaku. Sistem penghambat perilaku diaktifkan selama ada ancaman hukuman atau peningkatan kecemasan, sementara sistem aktivasi perilaku diaktifkan ketika ada isyarat lingkungan memfasilitasi pemberian hadiah, kesenangan, dan perilaku yang diarahkan pada tujuan. 
Individu dengan sistem aktivasi perilaku tinggi, berkembang pada perilaku mencari hadiah dan berisiko yang meningkatkan kadar dopamin di otak yaitu neurotransmitter yang terkait dengan kesenangan dan responsifitas terhadap hadiah (Gott \& Hetzel-Riggin, 2018).

Pendapat tersebut menjelaskan mengapa seorang menjadi pecandu. Pada umumnya individu mempunyai berbagai alasan pada penggunaan Napza pertama kali. Banyak individu menggunakan napza pertama kali di usia remaja. Sebagian mengatakan napza adalah jalan keluar ketika mempunyai masalah, sebagian lain mengatakan karena terpengaruh teman yang kadangkala disertai ancaman dan beberapa mengatakan karena coba-coba. Pada saat ini individu mulai menyalahgunakan napza. Penyalahguna yang mengkonsumsi napza terus menerus secara ilegal disertai dengan munculnya kenikmatan sesaat, memungkinkan berkelanjutan menjadi pecandu. Pada saat ini sistem aktivasi perilaku dari individu menjadi aktif, sehingga individu akan selalu mencari kesenangan sesaat yang selalu diulang. Saat inilah mulai munculnya kecanduan.

Saat individu menjadi pecandu, terjadi perubahan fisik, psikologis, perilaku, dan sosial. Perubahan fisik dapat terjadi tampak dalam kerusakan otak (Kipper \& Whitney, 2010), muncul berbagai penyakit seperti Tuberculosis (TBC), Human Immunodeficiency Virus_Acquired Immunodeficiency Syndrome (HIV-AIDS) dan Hepatitis C (BNN, 2015). Gangguan psikologis antara lain muncul dalam bentuk kecemasan dan depresi (Lai, Cleary, Sitharthan, \& Hunt, 2015). Gangguan perilaku dapat muncul dalam berbagai agresivitas (Barthelemy, Richardson, Cabral, \& Frank, 2016), perilaku seksual berisiko (Pillon, O'Brien, \& Chavez, 2005;
Ritchwood, DeCoster, Metzger, Bolland, \& Danielson, 2016), dan bahkan dapat mengarah pada kecenderungan perilaku percobaan bunuh diri (Dragisic, Dickov, Dickov, \& Mijatovic, 2015). Secara sosial, pecandu justru banyak berinteraksi dengan kelompok pecandu. Interaksi dengan orang lain lebih banyak diwarnai dengan kekerasan (Ansell, Laws, Roche, \& Sinha, 2015; Moore \& Stuart, 2005; Smith, Homish, Leonard, \& Collins, 2013). Pada pecandu juga mudah terlibat dengan perilaku kriminal yang merugikan orang lain (BNN, 2015; Rafaiee, Olyaee, \& Sargolzaiee, 2013).

Keluarga menjadi hal yang krusial karena interaksinya dalam keluarga yang bersifat resiprokal, saling memengaruhi antar anggotanya (Santrock, 2016). Pada umumnya, keluarga selalu ingin menjaga keseimbangan dalam interaksinya dengan anggota keluarga lain. Namun ketika ada anggota keluarga yang menjadi pecandu, keseimbangan emosi dan perilaku dalam keluarga menjadi tidak berfungsi dengan baik (Dayton, 2006). Kehidupan keluarga menjadi kacau, dukungan dan stabilitas berperilaku secara normal terganggu. Karena adiksi adalah gangguan yang bersifat progresif, secara perlahan pola hubungan antar anggota dapat menjadi semakin tidak normal (Dayton, 2006; Smith \& Estefan, 2014). Beberapa penelitian yang disitir oleh Smith \& Estefan (2014) menunjukkan efek negatif dari keberadaan pecandu di dalam keluarga dan respon emosi negatif yang menyertainya (Smith \& Estefan, 2014) dan bahkan keluarga dapat menjadi co-dependency (Rusnáková, 2014). Pada titik ini, keberadaan pecandu napza dalam keluarga dapat membuat keluarga menjadi disfungsional (Smith \& Estefan, 2014).

Jika ditilik dari sisi lingkungan, ada empat kategori yang ditengarai sebagai faktor risiko eksternal timbulnya adiksi: (1) 
Komunitas yang disfungsional (Kipper \& Whitney, 2010) yang antara lain adalah kemudahan dalam mendapatkan napza, pengangguran, dan masalah ekonomi (Pourmovahed, Yassini, Dehghani, \& Askari, 2013). (2) Keluarga yang tidak memberi kesempatan anak belajar perilaku konstruktif (Kipper \& Whitney, 2010) misalnya childhood maltreatment (abuse dan neglect), familial substance abuse, dan parentchild relationships (Whitesell, Bachand, Peel, \& Brown, 2013), atau orang tua yang adiktif (orang tua pecandu) (Rutherford \& Mayes, 2017). (3) Kelompok sebaya yang berperilaku menyimpang (Kipper \& Whitney, 2010), misalnya keterhubungan dengan kelompok peer yang menyimpang, popularitas, bullying, dan gang affiliation (Whitesell et al., 2013) atau berelasi dengan teman yang telah menjadi pecandu (Pourmovahed et al., 2013). (4) Lingkungan sekolah dan pekerjaan yang menekan (Kipper \& Whitney, 2010), misalnya membolos, atau kegagalan dalam mencapai prestasi belajar (Azad \& Hau, 2018).

Di lain sisi, faktor risiko internal yang mungkin hadir dari dalam diri individu sebagai faktor yang mempermudah munculnya kecanduan napza, antara lain rendahnya kontrol diri dan regulasi emosi (Jakubczyk et al., 2018; Kelly \& Bardo, 2016). Perkembangan kognisi yang tidak optimal juga ditengarai menjadi faktor risiko individual sehingga individu tidak dapat membuat keputusan dengan baik (Whitesell et al., 2013). Individu yang tidak dapat menunjukkan identitas diri positif dapat menjadi faktor risiko internal. Ketika seorang tidak mampu menunjukkan eksistensi dirinya secara positif, usaha untuk mencari eksistensi dapat mengarah pada kelompok yang dapat memberikan harga diri yang pada umumnya adalah kelompok peer deviant. Dalam hal ini tampak peran self-esteem (Pourmovahed et al., 2013) dan efikasi diri (Ibrahim, Kumar, \& Samah, 2011; Kadam, Sinha, Nimkar, Matcheswalla, \& De Sousa, 2017). Resiliensi sebagai kemampuan untuk tetap bertahan dalam situasi sulit (Wingo, Ressler, \& Bradley, 2014) terbukti berkorelasi dengan masalah penyalahgunaan napza.

Khususnya pada masa remaja yang sedang dalam masa pencarian jati diri (Santrock, 2016), usaha untuk mencapai kemandirian dan mencari identitas, mulai menjauh dari relasinya dengan orang tua, afiliasinya dengan kelompok sebaya semakin kuat. Dalam kondisi ini remaja cenderung mudah memenuhi tekanan kelompok sebaya, cenderung mudah mencoba perilaku berisiko (Kassel, Weinstein, Skitch, Veilleux, \& Mermelstein, 2005; Newman \& Newman, 2012; Steinberg, 2011). Oleh karena itu pengaruh teman sebaya adalah hal kritis pada remaja untuk mencoba aktivitas yang berbahaya, termasuk napza (Raesei, Sarani, Arbabisarjou, \& Mojahed, 2015), terutama jika disertai dengan regulasi emosi yang kurang optimal atau afek negatif dan impulsivitas (Kelly \& Bardo, 2016). Faktor risiko yang berasal dari keluarga, lingkungan, dan kepribadian dapat saling berinteraksi menjadi awal timbulnya adiksi (Kipper \& Whitney, 2010). Pendapat dan hasil penelitian di atas membuktikan bahwa aspek psikologis dan sosial yang negatif dapat mempunyai peran besar dalam munculnya kecenderungan penyalahgunaan bahkan dapat menjadi pecandu napza. Aspek-aspek ini saling berkaitan yang akhirnya seperti mengarah ke lingkaran setan yang menyebabkan rendahnya kualitas hidup individu (Fooladi et al., 2014).

Ketika seorang sampai ke taraf kecanduan, pada dirinya terjadi perubahan fisik, mental, sosial, dan emosi (Gordon \& 
Gordon, 1999). Banyak masalah akan muncul yang berbarengan dengan munculnya kecanduan pada diri seseorang.

\section{Masalah Belum Tertuntaskan}

Masalah penyalahgunaan dan kecanduan napza masih menjadi masalah besar yang belum dapat teratasi dengan tuntas baik secara nasional (BNN \& Puslitkes UI, 2015) maupun secara lebih luas (Caputo, 2019). Pada tahun 2014 diprediksi terdapat 3,8 juta hingga 4,1 juta penyalahguna napza di Indonesia (BNN, 2015). Peningkatan jumlah penyalahgunaan napza pada tahun 2020 bahkan diprediksi akan mencapai 5 juta orang dengan menggunakan skenario estimasi peningkatan penyalahguna dari tahun ke tahun. Masalah ini mengkhawatirkan karena penyalahgunaan napza dapat menimbulkan masalah pribadi, sosial, dan kesehatan yang berdampak negatif pada kualitas hidup (Fooladi, Jirdehi, \& Mohtasham-Amiri, 2014; Hoseinifar et al., 2011; Karow et al., 2010)

Fakta bahwa beberapa pecandu di Indonesia mengalami kekambuhan kembali setelah mengikuti proses rehabilitasi, juga terjadi di beberapa pusat rehabilitasi di negara di luar Indonesia. Dari suatu studi dengan menggunaan tinjauan naratif terhadap beberapa hasil penelitian di panti rehabilitasi narkoba menyimpulkan bahwa pecandu yang pernah mengkuti terapi, kadang masih menunjukkan kondisi abstinen dan relaps (Vanderplasschen et al., 2013). Narcotics anonymous, baik dilakukan sebagai metode lanjutan setelah individu menyelesaikan proses rehabilitasi. Ketika individu telah menyelesaikan proses rehabilitasi dan rajin dalam mengikuti kelompok NA, terbukti masa abstinennya lebih panjang (Gossop, Stewart, \& Marsden, 2007). Metode lain adalah obatobatan tradisional untuk pecandu napza yang dilakukan di China. Metode ini sulit diketahui efektivitasnya secara mandiri, karena digunakan sebagai terapi komplementer dengan metode lain ( $\mathrm{Zhu}$ et al., 2017). Dari laporan penelitian disebutkan bahwa uji klinis untuk pengobatan herbal masih jarang dilakukan (Lu et al., 2009). Penelitian lain dilakukan oleh Vanderplasschen et al (2013). Ia mengutip beberapa penelitian tentang relaps. Hasilnya menunjukkan angka relaps terendah 4\% dan tertinggi 94\%. Angka relaps yang lebih rendah ditemukan pada individu yang pernah mengikuti TC. Sementara itu di Tehran, ditemukan maksimum abstinen pada periode enam bulan (Sharifi et al., 2012).

Menilik kondisi relaps pecandu bahkan yang pernah mengikuti terapi, diduga ada permasalahan dasar yang belum terselesaikan sehingga kecanduan masih terus berulang. Bahkan, para pecandu yang telah pulih selama beberapa tahun dan berstatus konselor addict masih menyatakan adanya permasalahan dengan keluarga (Adiyanti et al., 2014)). Baik keluarga sebagai penyebab kecanduan ataupun kekacauan keluarga sebagai akibat dari keberadaan pecandu di dalamnya, keluarga yang disfungsional, para anggota keluarga tidak menjalankan peran sebagaimana mestinya bahkan dapat terjadi hubungan emosi negatif, terlebih dengan pecandu (Smith \& Estefan, 2014). Ada ketegangan atmosfer dalam keluarga dalam bentuk diskoneksi emosional (Dayton, 2006) yang perlu diperbaiki. Penelitian di Indonesia menemukan bahwa sebagian residen pecandu masih merasa belum cukup siap untuk kembali ke masyarakat karena ada kekhawatiran untuk bertemu dengan kelompok peer lama sebagai teman dalam penyalahgunaan napza (Adiyanti et al., 2014) Relasi dengan kelompok peer yang disfungsional ditemukan sebagai hal yang berkontribusi 
secara signifikan untuk munculnya kecanduan (Pourmovahed et al., 2013).

Di lain sisi, faktor risiko intenal seperti pengalaman penelantaran anak pada masa kecil (Rostami, Zarei, Zamiri, \& Larijani, 2010), impulsivitas (Kelly \& Bardo, 2016; Zilberman, Yadid, Efrati, Neumark, \& Rassovsky, 2018), kontrol diri (Flexon, Medrum, Young, \& Lehmann, 2016), regulasi emosi (Jakubczyk et al., 2018), selfesteem (Pourmovahed et al., 2013), kontrol perilaku (Abolghasemi \& Rajabi, 2013), resiliensi (Wingo et al., 2014), dan efikasi diri (Ibrahim et al., 2011; Kadam et al., 2017) perlu mendapatkan perhatian khusus dalam proses terapi. Pada penelitian di salah satu panti rehabilitasi di Indonesia ditemukan adanya kekhawatiran tentang masa depan serta ketidakmatangan emosi dan sosial pada mantan pecandu yang dinyatakan telah selesai mengikuti proses rehabilitasi (Adiyanti et al., 2014).

Banyak faktor yang menjadikan sebab, namun pertanyaan yang muncul adalah: bagaimana proses rehabilitasi yang dilakukan sehingga beberapa pecandu di Indonesia yang diwawancara menyatakan masih ada permasalahan dengan orang tua yang belum tuntas serta belum mempunyai keyakinan kuat kemampuan diri untuk mengatur perilakunya. Oleh karena itu, tulisan ini bertujuan untuk memunculkan proses terapi yang dapat dijadikan komplementer dengan metode yang sudah ada.

\section{Rehabilitasi: Proses Menuju Bersih dan Sehat}

Undang-undang Narkotika No 35 tahun 2009 pasal 54 menyatakan bahwa pecandu dan korban narkoba wajib menjalani rehabilitasi medis dan sosial. Selanjutnya pada pasal 55 dituliskan bahwa para pecandu atau keluarganya wajib melaporkan diri pada puskesmas, rumah sakit atau lembaga rehabilitas medis yang ditunjuk
(Sarasvita \& Raharjo, 2014). Artinya semua pecandu wajib untuk mengikuti proses rehabilitasi, baik medis maupun sosial. Meskipun demikian, dari data yang didapat belum semua pecandu berkesempatan untuk mengikuti proses rehabilitasi. Pada tahun 2017, ditengarai hanya 16 ribu dari 30 ribu pecandu ( $\pm 53 \%)$ yang dapat direhabilitasi (Sumantri, 2017).

Setiap rehabilitasi yang dilakukan, memfokuskan diri pada individu yang mengalami gangguan agar dapat menyesuaikan diri dengan baik, termasuk dengan keluarga dan support system-nya yang utama (Elliott \& Rath, 2011). Metode dan program rehabilitasi yang digunakan tergantung dari area psikologi dan teori yang dinilai sesuai dengan kondisi adiksi yang berada dalam lingkungan tertentu (Rath \& Elliott, 2012). Panti rehabilitasi untuk pecandu napza kurang lebih ditujukan untuk hal sama, yang penekanannya pada pemulihan fisik, sosial dan psikologis.

Di beberapa negara terdapat berbagai metode rehabilitasi bagi pecandu napza. De Leon (2000) merumuskan Therapeutic Community (TC), yang telah banyak diterapkan di Amerika, diteliti dan digunakan di beberapa negara. Penelitian yang melibatkan TC, antara lain di lakukan di Thailand (Johnson et al., 2012), Peru (Johnson et al., 2008), Korea (Lee, Shin, \& Park, 2014), Australia (Northam \& MagorBlatch, 2016), Belgia (Soyez, 2004), dan di Indonesia penelitian antara lain dilakukan oleh Fahrudin dan Nurdin (2010) dan Adiyanti dan Yuniarti (2015). Selain itu ada metode cognitive enhancement diteliti oleh Sofuoglu, DeVito, Waters, \& Carroll (2013). Environmental enrichment metode diteliti oleh Solinas Thiriet, Chauvet, \& Jaber (2010), sedangkan Wayman (2013) mengidentifikasi dan meneliti metode kelompok dan individual. Di China dikembangkan Chinese herbal medicine (Zhu, 
Zhang, Huang, \& Lu, 2017). Di Tehran dilakukan terapi outpatient-self therapy dan drug detoxification di pusat rehabilitasi (Sharifi et al., 2012). Disamping itu ada narcotics anonymous dan alcoholic anonymous yang di dasarkan pada 12 tradisi dan 12 langkah dan diteliti penerapannya pada kelompok penyandang HIV-AIDS (Orwat et al., 2011).

Dari beberapa sumber, tampaknya metode TC banyak dilakukan di beberapa negara, bahkan di Indonesia pun lebih banyak yang menggunakan metode TC daripada metode lain. Namun demikian TC yang dilaksanakan di beberapa panti tersebut, tampak pelaksanaannya telah mengalami modifikasi dari konsep TC yang dimaksudkan oleh penemunya, meskipun tujuan utamanya tidak berubah. Tujuan TC adalah melakukan rehabilitasi dan habilitasi terhadap kondisi kecanduan agar residen dalam TC dapat berfungsi seperti sedia kala. Tujuan ini dicapai melalui suatu proses yang dikatakan sebagai multidementional learning in the social context. Residen diajak untuk mengubah lifestyle-nya melalui program yang disusun dan terencana agar terjadi perubahan perilaku dan psikologis. Selanjutnya para pecandu diharapkan mampu melakukan self help dan mutual help untuk mengatasi kecanduannya (De Leon, 2000). Ketika proses berlangsung dengan baik dan benar, diharapkan para residen akan mengalami perubahan dalam cara berperilaku dan berpikir. Oleh karena itu perilaku keseharian dan sikap dalam berelasi dengan sesama residen maupun pengurus panti selalu dievaluasi dan dikoreksi.

Durasi rehabilitasi TC tradisional direncanakan selama 2 - 3 tahun yang dalam perkembangannya ada yang berubah menjadi 12-18 bulan (De Leon, 2000). Pada praktiknya TC di beberapa negara telah dilaksanakan dalam durasi waktu yang bervariasi, sebagai contoh TC yang dilaksanakan di Spanyol menggunakan durasi 9 bulan residential therapeutic community (Andez-Montalvo, López-Goñi, Illescas, Landa, \& Lorea, 2008). Para penyusun program pemulihan di Panti tentunya mempunyai pertimbangan yang mendasar tentang durasi terapi yang dilakukan seperti alasan berat ringannya kecanduan (Johnson et al., 2012), kesesuaian antara struktur program dengan kondisi pecandu dalam kultur tertentu (Sharifi et al., 2012) atau pertimbangan kebijakan lain. Lebih dari itu, hal ini tentunya harus diimbangi dengan program-program yang tertata dan terarah.

Therapeutic Community sebagai metode yang telah memiliki panduan pelaksanaan dan digunakan secara luas pun masih terus berkembang. Khususnya pada pelaksanaan TC di Indonesia yang pernah diobservasi dan dilakukan wawancara terhadap kepala panti atau orang yang mewakili, terindikasi adanya kesulitan menghadirkan keluarga dalam proses terapi. Family gathering dan parent support group yang seharusnya dihadiri oleh keluarga, kadang tidak semuanya hadir dan terlibat secara penuh.

Ada berbagai program dan materi yang disampaikan pada program yang berbasis TC. Di salah satu panti yang menerapkan TC yang dilakukan wawancara dan observasi, dalam penerapannya mengakomodasi beberapa program dengan materi, tujuan dan pelaksanaannya di lapangan digambarkan seperti pada Tabel 1. 
Tabel 1.

Contoh Pelaksanaan TC Ringkasan Evaluasi terhadap Pelaksanaan TC

\begin{tabular}{|c|c|c|c|c|}
\hline No & Nama Program & Materi & Tujuan & Pelaksanaan Lapangan \\
\hline 1. & $\begin{array}{l}\text { Morning meeting - } \\
\text { Morning tea }\end{array}$ & $\begin{array}{l}\text { - Belly check, } \\
\text { perencanaan } \\
\text { kegiatan harian, } \\
\text { - Membuka diri } \\
\text { dan terbuka } \\
\text { terhadap umpan } \\
\text { balik }\end{array}$ & $\begin{array}{l}\text { - Berbagi suasana } \\
\text { perasaan dan } \\
\text { kondisi fisik hari } \\
\text { itu } \\
\text { - Belajar menerima } \\
\text { umpan balik }\end{array}$ & $\begin{array}{l}\text { Kegiatan ini dilaksanakan dalam } \\
\text { kelompok, tidak semua residen } \\
\text { aktif dan mampu mengambil } \\
\text { pemaknaan dari mood check, disclose } \\
\text { dan feedback. Follow up yang } \\
\text { terbatas ketika residen dalam } \\
\text { kelompok menyatakan } \\
\text { perasaannya }\end{array}$ \\
\hline 2. & Function & $\begin{array}{l}\text { Mengerjakan } \\
\text { pekerjaan rumah } \\
\text { tangga }\end{array}$ & $\begin{array}{l}\text { - Mengembalikan } \\
\text { kepada ritme } \\
\text { kehidupan normal } \\
\text { - Belajar bertang- } \\
\text { gung jawab }\end{array}$ & $\begin{array}{l}\text { Klien diberi tugas mengurus } \\
\text { pekerjaan rumah tangga secara } \\
\text { bergilir }\end{array}$ \\
\hline 3. & Confrontation & $\begin{array}{l}\text { Terbuka terhadap } \\
\text { kelemahan }\end{array}$ & $\begin{array}{l}\text { Latihan menerima } \\
\text { kritik dengan cara } \\
\text { yang tepat }\end{array}$ & $\begin{array}{l}\text { - Confrontation dilakukan kepada } \\
\text { residen lain yang dianggap } \\
\text { melakukan kesalahan / } \\
\text { melanggar aturan rumah/nilai } \\
\text { yang dimiliki rumah } \\
\text { - Confrontation dilakukan dalam } \\
\text { frekwensi yang berkali-kali } \\
\text { sehingga terkesan bukan sebagai } \\
\text { upaya untuk membantu orang } \\
\text { lain tetapi mencari-cari kesa- } \\
\text { lahan yang dibuat orang lain } \\
\text { - Pelaksanaan dalam kelompok } \\
\text { sehingga terkesan pemaknaan } \\
\text { atas value dan penerapan dalam } \\
\text { kehidupan sehari-hari dari } \\
\text { kesalahan yang dilakukan masih } \\
\text { dalam batas “permukaan" }\end{array}$ \\
\hline 4. & Static group & $\begin{array}{l}\text { Problem solving dan } \\
\text { conflict resolution }\end{array}$ & $\begin{array}{l}\text { Belajar } \\
\text { menyelesaikan } \\
\text { masalah sesuai } \\
\text { dengan masalah } \\
\text { yang dihadapi - } \\
\text { coping behavior }\end{array}$ & $\begin{array}{l}\text { - Konselor mendampingi proses } \\
\text { resolusi konflik } \\
\text { - Dalam kelompok residen } \\
\text { mengomunikasikan masalah } \\
\text { kepada residen lain yang diang- } \\
\text { gap sebagai sumber konflik } \\
\text { - Residen menyampaikan konflik, } \\
\text { emosi dan kemarahan dalam } \\
\text { nada dan intonasi suara yang } \\
\text { tinggi namun tidak mengguna- } \\
\text { kan kalimat negatif seperti } \\
\text { penghinaan atau intimidasi } \\
\text { - Residen yang ditunjuk oleh } \\
\text { residen lain sebagai sumber } \\
\text { konflik harus bersikap tenang } \\
\text { dan penuh kontrol menerima } \\
\text { luapan amarah dari residen lain. }\end{array}$ \\
\hline
\end{tabular}




\begin{tabular}{|c|c|c|c|c|}
\hline No & Nama Program & Materi & Tujuan & Pelaksanaan Lapangan \\
\hline 5. & $\begin{array}{l}\text { Seminar topikal } \\
\text { ditetapkan } 3 \\
\text { bulan: adiksi dan } \\
\text { psikologi }\end{array}$ & $\begin{array}{l}\text { Knowledge tentang } \\
\text { adiksi dari } \\
\text { konselor }\end{array}$ & $\begin{array}{l}\text { Meningkatkan } \\
\text { pemahaman tentang } \\
\text { adiksi }\end{array}$ & $\begin{array}{l}\text { Kuliah, diberikan oleh addict dan } \\
\text { atau konselor addict. Kuliah } \\
\text { diberikan dalam kelompok besar }\end{array}$ \\
\hline 6. & Hair Cut & $\begin{array}{l}\text { Evaluasi aktivitas } \\
\text { hari ini }\end{array}$ & $\begin{array}{l}\text { Melakukan } \\
\text { refleksi/teguran } \\
\text { tentang pekerjaan, } \\
\text { mengevaluasi dan } \\
\text { memaknai }\end{array}$ & $\begin{array}{l}\text { Dilakukan bersama HOD dengan } \\
\text { beberapa orang rekan sebaya. }\end{array}$ \\
\hline 7. & Chair & $\begin{array}{l}\text { Sangsi atas } \\
\text { kesalahan }\end{array}$ & $\begin{array}{l}\text { Bertanggung jawab } \\
\text { atas pekerjaan }\end{array}$ & $\begin{array}{l}\text { - Residen yang melakukan } \\
\text { pelanggaran berat terhadap } \\
\text { aturan rumah dan/atau } \\
\text { melakukan perbuatan yang } \\
\text { tidak bertanggungjawab } \\
\text { - Keputusan untuk memberikan } \\
\text { sanksi chair ditentukan oleh } \\
\text { HOD, Chief dan Konselor } \\
\text { - Chair dilakukan dengan cara } \\
\text { menyuruh residen untuk duduk } \\
\text { di sebuah kursi “sendiri" sambil } \\
\text { menghadap sebuah tembok. Ia } \\
\text { tidak boleh berkomunikasi } \\
\text { dengan siapapun, tidak boleh } \\
\text { melakukan aktivitas apapun } \\
\text { selain hanya duduk } \\
\text { - Residen boleh makan dan } \\
\text { minum yang diberikan oleh } \\
\text { residen lain. Dia juga hanya } \\
\text { boleh ke kamar mandi setelah } \\
\text { mendapatkan izin }\end{array}$ \\
\hline 8. & Drop Guilty & $\begin{array}{l}\text { Merenungi } \\
\text { kesalahan }\end{array}$ & $\begin{array}{l}\text { Refleksi diri, } \\
\text { melakukan } \\
\text { penilaiana diri }\end{array}$ & $\begin{array}{l}\text { Dalam posisi duduk, residen yang } \\
\text { dikenai sanksi juga diminta } \\
\text { merenungkan, merefleksikan dan } \\
\text { menuliskan berbagai dosa yang } \\
\text { dilakukan selama hidupnya } \\
\text { termasuk selama mengikuti } \\
\text { kegiatan residensial. Penulisan itu } \\
\text { dilakukan berulang-ulang sesuai } \\
\text { ketentuan sanksi yang harus } \\
\text { dijalani residen. Tujuan dari } \\
\text { kegiatan ini adalah agar residen } \\
\text { menjadi mengenali dan menyadari } \\
\text { berbagai perbuatan yang telah ia } \\
\text { lakukan kepada orang lain, } \\
\text { lingkungan dan dirinya sendiri. } \\
\text { Berbagai perbuatan yang telah } \\
\text { merugikan dan menyakiti orang } \\
\text { lain }\end{array}$ \\
\hline & Meeting & $\begin{array}{l}\text { Evaluasi harian } \\
\text { oleh MOD }\end{array}$ & $\begin{array}{l}\text { Melakukan evaluasi } \\
\text { kegiatan harian }\end{array}$ & $\begin{array}{l}\text { Evaluasi kegiatan harian yang } \\
\text { dilakukan dalam kelompok }\end{array}$ \\
\hline
\end{tabular}




\begin{tabular}{|c|c|c|c|c|}
\hline No & Nama Program & Materi & Tujuan & Pelaksanaan Lapangan \\
\hline 10. & Outing & $\begin{array}{l}\text { Aktivitas bersama } \\
\text { di luar panti }\end{array}$ & $\begin{array}{l}\text { Mengatasi kejenuh- } \\
\text { an, meningkatkan } \\
\text { keterlibatan } \\
\text { kelompok }\end{array}$ & $\begin{array}{l}\text { Dilakukan setiap } 6 \text { bulan sekali } \\
\text { Dilakukan dalam kelompok besar }\end{array}$ \\
\hline 11. & $\begin{array}{l}\text { Family Support } \\
\text { Group }\end{array}$ & $\begin{array}{l}\text { Komunkasi dengan } \\
\text { orangtua dan } \\
\text { menyelasikan } \\
\text { masalah dalam } \\
\text { keluarga }\end{array}$ & $\begin{array}{l}\text { Membahas berbagai } \\
\text { permasalahan yang } \\
\text { terjadi dalam } \\
\text { kehidupan residen } \\
\text { dalam kaitannya } \\
\text { dengan kasus adiksi }\end{array}$ & $\begin{array}{l}\text { - Keluarga dipertemukan dengan } \\
\text { residen } \\
\text { - Konselor melakukan konseling } \\
\text { keluarga untuk mengetahui peta } \\
\text { permasalahan keluarga dan } \\
\text { residen } \\
\text { - Membahas langkah-langkah } \\
\text { pemulihan residen bersama } \\
\text { keluarga } \\
\text { - Hal-hal yang menjadi } \\
\text { penghambat dan pendukung } \\
\text { pemulihan residen }\end{array}$ \\
\hline 12. & Family Gathering & $\begin{array}{l}\text { Pertemuan antara } \\
\text { anak dan orangtua }\end{array}$ & $\begin{array}{l}\text { Meningkatkan } \\
\text { kemampuan } \\
\text { komunikasi antara } \\
\text { orangtua dan anak } \\
\text { serta meningkatkan } \\
\text { kemampuan untuk } \\
\text { saling memahami }\end{array}$ & $\begin{array}{l}\text { Pertemuan antara anak dan } \\
\text { orangtua serta anggota keluarga } \\
\text { lain. Family gathering pada umum- } \\
\text { nya dilakukan dalam kelompok, } \\
\text { hanya jika diperlukan, dilakukan } \\
\text { pertemuan antara orangtua dan } \\
\text { anak dengan seorang konselor. }\end{array}$ \\
\hline 13. & $\begin{array}{l}\text { Konseling } \\
\text { Individu }\end{array}$ & $\begin{array}{l}\text { Individu } \\
\text { mengajukan diri } \\
\text { untuk berbicara } \\
\text { dengan konselor }\end{array}$ & $\begin{array}{l}\text { Membahas problem } \\
\text { individual, sharing } \\
\text { dan alternatif solusi }\end{array}$ & $\begin{array}{l}\text { Satu individu bertemu dengan } \\
\text { satu konselor. Residen dapat } \\
\text { melakukan konseling dengan } \\
\text { konselornya yang telah ditentukan } \\
\text { untuk dirinya maupun dengan staf } \\
\text { konselor lain yang bertugas saat } \\
\text { itu. Kegiatan ini dilakukan atas } \\
\text { inisiatif residen ataupun konselor }\end{array}$ \\
\hline 14. & $\begin{array}{l}\text { Konseling } \\
\text { kelompok }\end{array}$ & $\begin{array}{l}\text { Konselor } \\
\text { menunjuk } \\
\text { beberapa orang } \\
\text { yang dinilai } \\
\text { mampu untuk } \\
\text { menjalankan }\end{array}$ & $\begin{array}{l}\text { Ekspresi perasaan, } \\
\text { memberi, dan } \\
\text { menerima saran }\end{array}$ & $\begin{array}{l}\text { Seorang konselor melakukan } \\
\text { konsultasi dengan beberapa } \\
\text { residen secara bersamaan dalam } \\
\text { kelompok agar terjadi interaksi } \\
\text { saling mendukung satu sama lain } \\
\text { antara residen }\end{array}$ \\
\hline
\end{tabular}

Panti rehabilitasi lain yang menggunakan pendekatan agama memberikan materi dengan penekanan utamanya aktivitas relijius. Proses penyembuhannya didasarkan pada prinsip-prinsip dan ritual yang berorientasi pada agama. Namun demikian tidak semua panti yang melakukan terapi agama mempunyai progam sama, kecuali program yang sifatnya kerohanian. Program-program lain tidak mesti dilaksanakan di setiap panti yang mendasarkan diri pada agama. Beberapa panti yang mendasarkan diri pada agama Islam, berbentuk pondok pesantren sehingga setiap residen di samping melakukan proses terapi, juga dibimbing untuk lebih mengenal dan mendalami agama. Berikut adalah rangkuman program beberapa panti yang menggunakan pendekatan agama. 
Tabel 2 .

Contoh Ringkasan Terapi Berbasis Agama

\begin{tabular}{|c|c|c|c|}
\hline Nama Program & Materi & Tujuan & Pelaksanaan Lapangan \\
\hline Kerohanian & $\begin{array}{l}\text { Agama sesuai dengan } \\
\text { visi panti/pendalaman } \\
\text { rohani. }\end{array}$ & $\begin{array}{l}\text { Menenangkan dan } \\
\text { menyembuhkan } \\
\text { pecandu - mende- } \\
\text { katkan diri dengan } \\
\text { Allah. }\end{array}$ & $\begin{array}{l}\text { Melakukan ritual agama sesuai } \\
\text { dengan prinsip-prinsip yang } \\
\text { diikuti oleh setiap panti. } \\
\text { Dilakukan oleh ahli } \\
\text { agama/rohaniawan. }\end{array}$ \\
\hline Detoksifikasi & Medis ataupun alami. & $\begin{array}{l}\text { Memberihkan dari } \\
\text { pengaruh napza. }\end{array}$ & $\begin{array}{l}\text { Medis: dengan program medis } \\
\text { dilaksanakan oleh ahli } \\
\text { medis/dokter. } \\
\text { Alami tanpa obat-obat, misal } \\
\text { dengan air kelapa. }\end{array}$ \\
\hline $\begin{array}{l}\text { Metode } \\
\text { pendamping }\end{array}$ & Konsultasi, sharing. & $\begin{array}{l}\text { Pembinaan mental. } \\
\text { Terapi psikososial. }\end{array}$ & $\begin{array}{l}\text { Dilaksanakan/dibimbing oleh } \\
\text { rohaniawan dapat berbentuk } \\
\text { aktivitas kelompok maupun } \\
\text { individual. }\end{array}$ \\
\hline Outing & $\begin{array}{l}\text { Olah raga, kegiatan } \\
\text { lain di luar terapi } \\
\text { rutin. }\end{array}$ & $\begin{array}{l}\text { Memberikan } \\
\text { kesegaran. }\end{array}$ & $\begin{array}{l}\text { Senam bersama, kegiatan yang } \\
\text { tidak berkaitan dengan masalah } \\
\text { adiksi. }\end{array}$ \\
\hline
\end{tabular}

\section{Therapeutic Community Sebagai Pilihan}

Berdasarkan kajian di atas, disimpulkan bahwa Therapeutic Community merupakan metode terapi untuk pecandu yang banyak diterapkan, baik secara lokal (Indonesia) maupun secara lebih luas (di luar Indonesia). Model, struktur, dan program yang di susun oleh De Leon (2000) sangat jelas. Bukti empiris yang menunjukkan keberhasilan serta kegagalan dalam pemulihan pecandu juga telah banyak diteliti, meskipun hasilnya bervariasi. Khususnya pada pelaksanaan TC di Indonesia, pertimbangan terebut mendasari pilihan usulan ide komplementer untuk metode TC.

Dalam tulisannya tentang Therapeutic Community, De Leon (2000) menyebutkan bahwa pada dasarnya aktivitas TC ditujukan untuk behavior management shaping dan emotional and psychological recovery. Program yang yang direncanakan seharusnya terdiri dari beberapa kelompok aktivitas (National Institute on Drug Abuse, 2015): (1) Pertemuan dengan komunitas TC (e.g. Morning meeting, daily house, general meeting dan seminars). (2) Meriviu tujuan dalam TC, prosedur TC, dan fungsi TC. (3) Pekerjaan individu dan kelompok dalam TC (encounter groups, retret) yang berfokus pada perubahan pola pikir dan perilaku negatif dan membangun self-efficacy sehingga residen belajar untuk menjadi motivator bagi dirinya sendiri untuk berubah.

Proses pemulihan dalam TC diarahkan pada self help dan mutual help. Untuk mencapai kondisi clean and sober dalam suasana self help dan mutual help, program TC mengikuti tiga tahap yaitu induction, primary dan re-entry (De Leon, 2000).

Tahap induction. Tahap ini bertujuan untuk melakukan orientasi program TC. Diharapkan residen memahami proses yang ada di TC (termasuk dasar filosofinya) yang dikaitkan dengan keinginannya 
untuk sembuh, serta melakukan penyesuaian dalam komunitas. Jika residen telah dinilai memahami dan dapat menyesuaikan diri, maka direkomendasikan naik ke tahap berikutnya. Waktu yang dibutuhkan 30 hari.

Tahap primary. Dalam proses rehabilitasi tahap ini berfokus pada pengembangan sosial dan psikologi residen. Aktivitas yang telah disusun diharapkan mampu untuk mencapai tujuan tersebut sehingga residen mengalami pengembangan diri. Waktu yang dibutuhkan 6-9 bulan yang terdiri dari 3 status didasarkan pada progress residen, yaitu: younger, middle, dan older. Tidak semua program TC melaksanakan seperti yang disebutkan

Tahap re-entry. Tahap ini memfasilitasi residen untuk dapat bersosialisasi dengan kehidupan di luar panti. Residen melakukan latihan-latihan dan memaknainya sehingga perilaku dan sikapnya dapat mengikuti aktivitas normal di luar panti. Terapi ini berjalan 3-6 bulan.

Meskipun banyak variasi waktu dalam pelaksanaan TC, namun jelas terbukti bahwa semakin lama waktu dilaksanakannya perlakuan semakin baik outcome yang diperoleh semakin lebih baik (De Leon, 2000; Vanderplasschen et al., 2013). Hal ini sangat bisa dimengerti karena untuk perubahan pola pikir, membangun self-efficacy dari seorang pecandu yang mengalami "perubahan fisik, mental, spiritual, dan perilaku" (Gordon \& Gordon, 1999) bukan masalah yang mudah dan cepat terselesaikan.

Penelusuran terhadap metode TC yang dilaksanakan di beberapa tempat di Indonesia, tampak perlunya program komplementer yang melengkapi sehingga problem psikologis yang belum tertangani mendapatkan kesempatan untuk dipulihkan. Di beberapa panti rehabilitasi berbasis TC, program mengolah permasalahan psikologis sebetulnya telah dilakukan namun demikian tampaknya tidak semua dilaksanakan secara konsisten dan berkesinambungan. Data dari penelitian di salah satu panti rehabilitasi menemukan bahwa proses rehabilitasi dengan menggunakan TC tidak dilaksanakan secara penuh dan residen telah dinyatakan sembuh setelah mengikuti proses tersebut (Amalia, 2016). Beberapa hal yang ditengarai menjadi penyebabnya adalah: durasi proses rehabilitasi, faktor risiko internal dan eksternal yang menyebabkan individu mudah terkontaminasi dengan napza, belum tertangani.

\section{Durasi dan Proses Rehabilitasi}

Dari hasil penelitian yang dilakukan, proses terapi dalam TC paling cepat diselesaikan dalam waktu 4 bulan dan paling lama 1 tahun, yang semestinya tidak terlalu banyak berbeda dengan pelaksanan TC di beberapa tempat yang lain. Namun demikian yang harus lebih dikritisi adalah apakah program yang dilaksanakan sudah memenuhi kebutuhan akan penyelesaian masalah-masalah psikologis pecandu. Dalam satu penelitiannya, Jarvinen (2017) menuliskan bahwa terapi semestinya dapat mengubah "keinginan" residen untuk sembuh menjadi "kebutuhan" residen untuk sembuh. Hal yang juga harus dipertimbangkan adalah fokus pada halhal yang lebih mendasari kecanduannya. Terapi yang dilakukan tampaknya belum mengarah ke hal-hal yang mendasar karena pada TC yang dilaksanakan lebih memusatkan pada masalah perilaku selama di rehabilitasi (misalnya morning meeting atau function sebagaimana yang tertera pada tabel 1 yang harapannya dapat ditransfer ketika residen telah keluar dari panti. Namun pada kenyataannya masih timbul masalah-masalah psikologis yang belum terselesaikan saat proses di panti 
(Adiyanti \& Yuniarti, 2015). Jangka waktu yang pendek diduga merupakan salah satu kemungkinan sebab belum tercapainya dan terselesaikannya masalah-masalah yang menjadi sebab utama munculnya kecanduan.

\section{Keluarga sebagai Faktor Eksternal}

Keluarga memiliki andil dalam munculnya adiksi (Whitesell et al., 2013). Demikian pula hasil penelitian pada pecandu yang mengikuti rehabilitasi di Indonesia, dengan keluarga dan kelompok peer, perilaku risiko penyalahgunaan NAPZA pada lakilaki dipengaruhi oleh faktor kelekatan ayah-anak, kelekatan ibu-anak, keterlibatan kegiatan waktu luang, kelekatan teman sebaya, dan perilaku merokok (Purwandari, 2015). Keluarga juga dapat menjadi disfungsional ketika di dalamnya ada salah satu anggotanya yang menjadi pecandu (Smith \& Estefan, 2014). Dari penelusuran yang dilakukan (lihat Tabel 2) melalui kegiatan family gathering ataupun familly support group yang dilaksanakan pada saat-saat tertentu, belum mencukupi untuk dapat menyelesaikan masalah yang berkaitan dengan keluarga. Salah satu bekas yang masih terbawa adalah adanya hubungan dengan ayah dan ibu yang belum terselesaikan dengan tuntas walaupun mantan pecandu telah mengikuti proses rehabilitasi (Adiyanti \& Yuniarti, 2015).

\section{Faktor Risiko Internal}

Dari sisi faktor risiko internal, beberapa penelitian menunjukkan bahwa faktor psikososial (Azmi, Hussin, Ishak, \& Daud, 2018) seperti kontrol diri (Flexon et al., 2016) dan resiliensi (Wingo et al., 2014) terbukti berkorelasi dengan masalah penyalahgunaan napza. Selain itu, faktor psikologi seperti efikasi diri (Ibrahim et al., 2011; Kadam et al., 2017) merupakan faktor yang dapat melindungi pecandu yang telah menjalani rehabilitasi untuk mengalami relaps. Disamping itu juga telah diketemukan adanya peran aspek kognitif baik dalam proses timbulnya masalah (Whitesell et al., 2013) maupun dalam proses percepatan kesembuhan (Kusrohmaniah, 2004). Konten proses pemulihan juga belum banyak menyentuh aspek psikologis secara mendalam yang justru ditengarai menjadi penyebab utama faktor internal yang menyebabkan masalah kecanduan.

Berdasarkan hasil penelitian oleh beberapa peneliti di beberapa negara, telah disebutkan di atas bahwa TC membawa dampak perubahan yang cukup signifikan. Namun demikian Malivert, Fatseas, Denis, Langlois, dan Auriacombe (2012) memberikan peringatan, bahwa setelah mengikuti program TC tampak ada penurunan konsumsi, tetapi manfaat jangka panjang belum pasti. Studi selanjutnya disarankan untuk membandingkan kemanjuran program TC dan jenis program lain untuk gangguan terkait napza. Di Indonesia, Penelitian Prianto (2007) menyimpulkan keberhasilan TC di PSPP Sehat Mandiri sebesar 24\% dari keseluruhan residen yang masuk program sejak tahun 2004. Penelitian lain di salah satu pusat rehabilitasi yang menggunakan metode TC, setiap tahun ditemukan pecandu yang relaps, meskipun telah mengikuti proses rehabilitasi.

Dalam laporan penelitian tentang pelaksanaan TC salah seorang informan melaporkan bawa beberapa residen mengevaluasi program TC yang dilaksakan di panti di mana residen tersebut melakukan proses rehabilitasi. Mereka mengatakan bahwa intensitas program TC sangat menantang namun juga melelahkan dan membosankan. Hampir sama dengan kondisi tersebut, penelitian Prangley, Pit, 
Rees, dan Nealon (2018) menuliskan penilaian residen yang menggambarkan terapi sebagai "melelahkan dan tanpa henti", dan merasa sulit untuk terbuka tentang perasaan dan trauma masa lalu. Jika memperhatikan alasan para pecandu masuk ke Panti rehabilitasi, ditemukan beberapa alasan: keterpaksaan (dibawa oleh polisi, "ditipu orang tua", dibawa oleh saudara dsb) dan hanya sedikit yang menyatakan keinginan untuk sembuh. Motivasi yang lemah untuk mengikuti proses terapi di Panti Rehabilitasi dapat menjadi salah satu sebab kegagalan proses terapi.

\section{Program Komplementer Therepeutic Community}

Dalam konsep TC ada dua hal yang ditekankan yaitu self help dan mutual help (De Leon, 2000) yang telah dilatihkan selama proses rehabilitasi dalam panti. Untuk memperkuat hasil sehingga mantan pecandu benar-benar dalam kondisi "clean and sober" atau setidaknya waktu abstinen menjadi lebih panjang, beberapa hal yang disarankan dalam proses terapi adalah: (1) Mengubah "keinginan" menjadi "kebutuhan" untuk menjalani proses terapi untuk pemulihan dan mencapai kondisi "clean and sober" mengadopsi pokok-pokok pikiran Jarvinen (2017). Konsep ini dapat dimasukan ke dalam tahap induction sebagai salah satu cara memunculkan motivasi yang besar untuk menjalankan proses rehabilitasi. (2) Mengidentifikasi secara lebih cermat faktor-faktor risiko dan protektif dalam diri individu (faktor internal). Proses rehabilitasi dikaitkan dengan program-program mengurangi faktor risiko internal diharapkan dapat meningkatkan ketangguhan mantan pecandu ketika menghadapi lingkungan yang disfungsional baik komunitas (Kipper \& Whitney, 2010) maupun peer (Whitesell et al., 2013) atau teman pecandu (Pourmovahed et al., 2013). Jika hal ini dapat dilakukan pada tahap induksi akan berguna untuk penyusunan program berikutnya. Salah satu hal yang dapat dilakukan adalah memberikan kesempatan pada pecandu untuk mempelajari kondisi dirinya melalui analisis berbasis psikologi yang diuraikan secara sederhana, misalnya konsep keperilakuan tentang timbulnya adiksi. Karena aktivitas ini membutuhkan waktu yang lebih panjang maka pelaksanaannya dapat dilakukan pada tahap primary dan lebih meningkat serta mendalam pada proses re-entry, dalam aktivitas seminar atau diskusi. (3) Khususnya keluarga mempunyai peran besar dalam proses kecanduan. Interaksi resiprokal antar anggota keluarga (Santrock, 2016) dapat menjadikan keluarga sebagai salah satu penyebab munculnya kecanduan (Kipper \& Whitney, 2010; Rutherford \& Mayes, 2017; Whitesell et al., 2013) namun sekaligus dapat menjadi korban dari keberadaan pecandu (Dayton, 2006; Smith \& Estefan, 2014), perlu mendapatkan perhatian khusus. Pemulihan perlu diarahkan pada permasalahan dalam keluarga, baik hubungan individu dengan orang tuanya maupun juga keluarga yang menjadi korban. Bentuk-bentuk terapi keluarga akan sangat membantu. Barangkali, salah satu kendala yang dihadapi adalah rutinitas keterlibatan keluarga dalam mengikuti proses terapi seperti yang didapatkan dari hasil wawancara dalam penelusuran ini. Kesiapan keluarga untuk mengikuti proses terapi diperlukan dan diinformasikan sejak residen ada di fase induksi. Keterlibatan keluarga kemungkinan akan lebih besar ketika dilakukan secara meningkat dari fase primary sampai re-entry. (4) Ukuran keberhasilan untuk naik status dari satu tahap ke tahap berikutnya seyogyanya dilakukan secara lebih cermat dengan 
melibatkan aspek-aspek perubahan perilaku, aspek kognitif, kemampuan mental dan emosi, dan sosial sesuai dengan tuntan tiap tahapnya. Untuk itu diperlukan alat asesmen terstandar dan kemampuan observasi dan wawancara secara lebih mendalam. (5) Untuk menjalankan hal tersebut, diperlukan profesional yang berkompeten di bidangnya. Ide untuk mengintegrasikan penyelesaian masalahmasalah psikologis ke dalam proses TC yang telah dilaksanakan secara lebih terstruktur serta membuat terapi yang panjang dapat memotivasi residen, perlu adanya alternatif aktivitas. Jika digambarkan dalam bagan, maka tergambar seperti pada Gambar 3.

\section{Program Lanjutan}

Adiksi Napza (termasuk di dalamnya kecanduan alkohol) masalah interaksi antara sejumlah kelainan, penyimpangan dan penyakit medis, sosial, dan psikologis (Hadži-Pešić, Mitrović, Car, \& Stojanović, 2014). Fakta bahwa masa abstinen setelah mengikuti proses rehabilitasi sangat bervariasi dan masih terdapat mantan pecandu yang relaps, maka diperlukan usaha pemulihan terus menerus di luar panti.

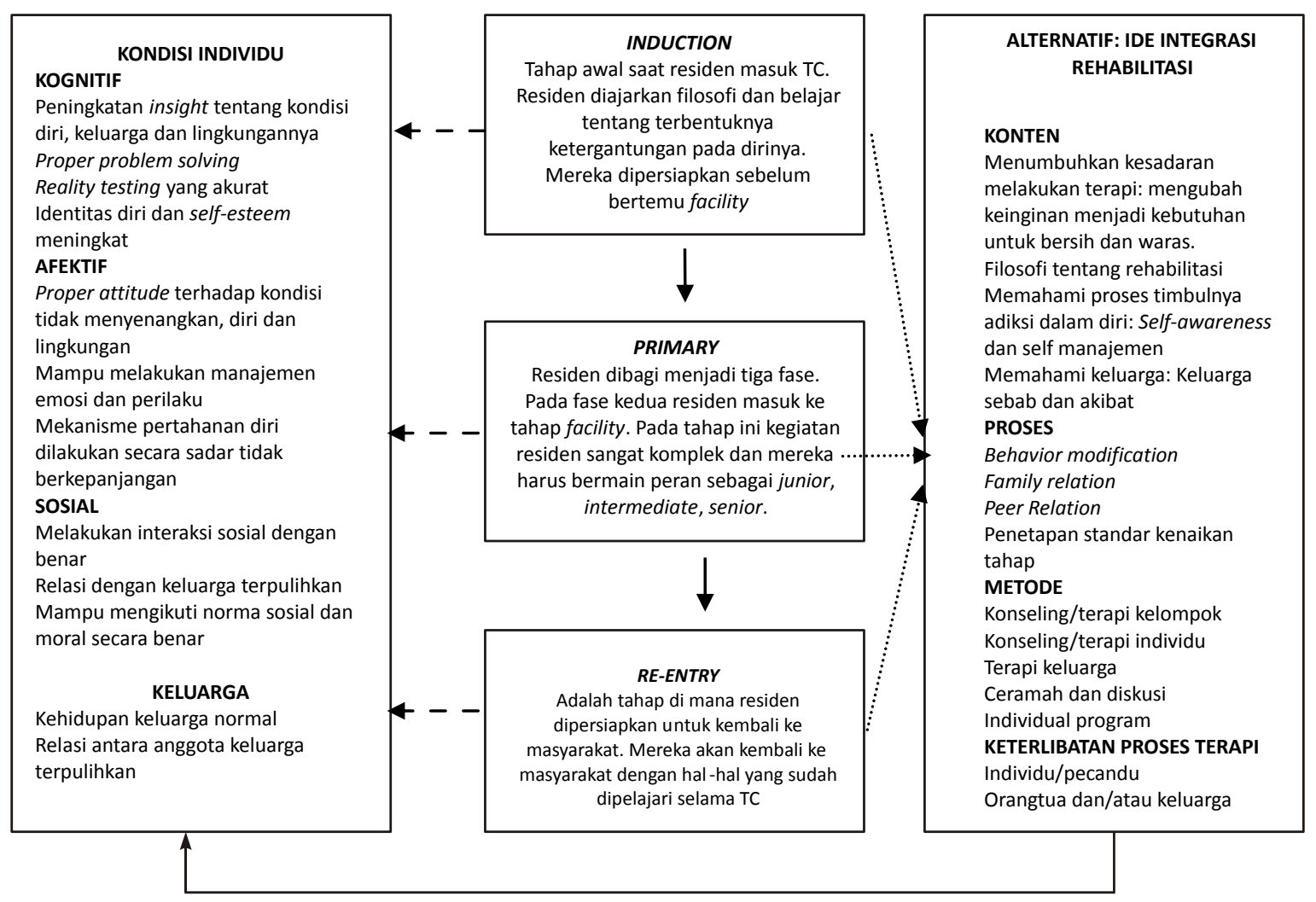

Gambar 3. Pokok-pokok usulan integrasi proses rehabilitasi di TC

Keterangan :

Memberi efek rehabilitatif

Tahap selanjutnya

Berisi tentang 
Dalam upaya mencapai perubahan optimal, metode analisis konfigural pada primary prevention practices (Bloom, 1996) diperkirakan dapat membantu mengatasi masalah. Metode tersebut digambarkan sebagai berikut: (1) Person (afektif, kognitif, behavioral, physiological dan biological aspects) adalah komponen utama yang mendapatkan intervensi. Ketika individu sudah berada di luar panti, maka harus selalu diusahakan secara terus menerus dan berkesinambungan untuk tetap meningkatkan kekuatan individu agar kelemahan-kelemahannya dapat tertutupi oleh kekuatan yang ada pada dirinya. (2) Lingkungan sosial adalah mereka yang berinteraksi langsung dengan individu. Pada umumnya setelah individu menyelesaikan proses terapi, untuk kembali ke lingkungan masih ada stigma pecandu yang melekat (Johnson et al., 2008). Hal ini dapat menimbulkan social stress pada individu. Oleh karena itu mengurangi memberikan label sebagai pecandu diperkirakan akan mengurangi social stress.

Pembicaraan mengenai kelompok sosial, ada beberapa kelompok sosial yang dapat memberikan dukungan: (1) Primary groups. Dalam kaitannya dengan pemulihan adiksi narkoba, juga jelas bahwa program pencegahan perlu melibatkan dan memanfaatkan keluarga untuk membantu memperkuat ketahanan dan kemampuan individu (Zamani, Nasir, Desa, Khairudin, \& Yusooff, 2014). (2) Secondary groups adalah orang-orang yang tidak berinteraksi langsung dengan klien, misalnya kelompok peers, guru dan teman-teman di sekolah.

Physical environment adalah semua kondisi fisik yang ada relasinya dengan klien. Ketika klien ada di panti rehabilitasi, physical environment telah terjaga. Namun ketika berada di luar panti, physical environment lebih luas dan kadang justru menimbulkan ingatan untuk kembali menggunakan narkoba (sugesti). Lingkungan di luar harus ikut ditata untuk mengurangi efek sugesti tersebut. Hal ini didasarkan pada bukti bahwa pecandu napza yang berada pada high-risk situation termasuk lingkungan dimana pecandu biasa menyalahgunakan napza dapat memicu relaps (Larimer, Palmer, \& Marlatt, 1999).

Bloom menggambarkan interaksi dari ketiga aspek tersebut seperti Gambar 2.

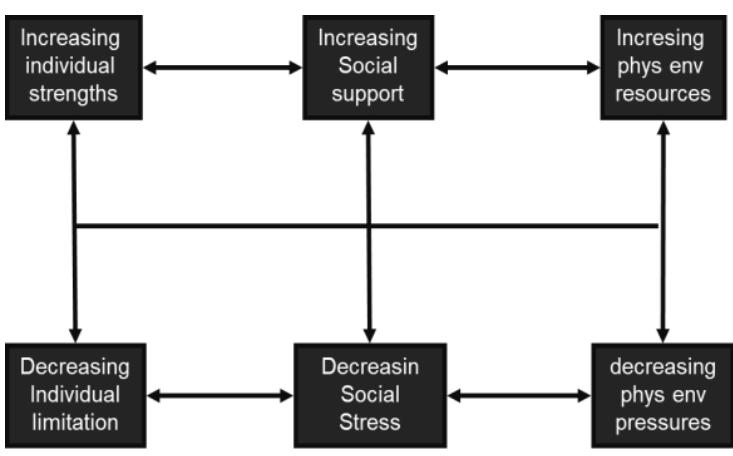

Gambar 2. The Configural Equation (Bloom, 1996)

\section{Penutup}

Pada dasarnya TC merupakan metode yang komprehensif dan banyak digunakan, namun perlu penekanan pada masalahmasalah psikologis dasar yang menyebabkan timbulnya kecanduan. Usulan pengayaan/integrasi program TC yang dilanjutkan dengan program di luar panti merupakan suatu proses yang diharapkan dapat menstimulasi dan memfasilitasi pertumbuhan psikologis baik pada diri individu maupun keluarganya. Oleh karena itu, diusulkan untuk memberikan tema "Pertumbuhan Psikologis" melalui program TC dan komunitas. Di samping itu, program lanjutan diluar panti bagi mantan pecandu perlu dilakukan secara serempak dengan melibatkan lingkungan yang mempunyai peran dalam kehidupan individu. 
Usulan progam ini bersifat analisa teoritis dan hipotetis. Oleh karena itu, untuk penerapan dan pelaksanaannya perlu dilakukan penelitian empiris lebih lanjut dengan membandingkan hasil rehabilitasi dari metode dan program rahabilitasi yang telah ada.

\section{Daftar Pustaka}

Abolghasemi, A., \& Rajabi, S. (2013). The role of self-regulation and affective control in predicting interpersonal reactivity of drug addicts. International Journal of High Risk Behaviors and Addiction, 2(1), 28-33. doi: 10.5812/ ijhrba.9919

Adiyanti, M. G., \& Yuniarti, K. W. (2015). Memaknai kondisi residen therapeutic community. Laporan Penelitian. Yogyakarta: Fakultas Psikologi Universitas Gadjah Mada.

Adiyanti, M. G., Yuniarti, K. W., \& Yana, I. P. (2014). Makna therapeutic community bagi konselor addict. Laporan Penelitian. Yogyakarta: Fakultas Psikologi Universitas Gadjah Mada.

Amalia, N. (2016). Efektivitas program rehabilitasi bagi korban penyalahgunaan NAPZA melalui pendekatan therapeutic community oleh lembaga Kunci Nandan. Skripsi (tidak dipublikasikan. Yogyakarta: Fakultas Ilmu Sosial dan Ilmu Politik Universitas Gadjah Mada.

Andez-Montalvo, J., López-Goñi, J. J., Illescas, C., Landa, N., \& Lorea, I. (2008). Evaluation of a therapeutic community treatment program: A long-term follow-up study in Spain. Substance Use \& Misuse, 43(10), 1362 1377. doi: $\underline{10.1080 / 10826080801922231}$

Ansell, E. B., Laws, H. B., Roche, M. J., \& Sinha, R. (2015). Effects of marijuana use on impulsivity and hostility in daily life. Drug and Alcohol Dependence, 148, 136-142. doi: 10.1016/ j.drugalcdep.2014.12.029

Azad, A., \& Hau, H. G. (2018). Adolescent females with limited deliquency - at risk of school failure. Children and Youth Service Review, 95, 384-396.

Azmi, A. A., Hussin, H., Ishak, S. I. D., \& Daud, N. S. (2018). Drug addicts: Psychosocial factor contributing to relapse. MATEC Web of Conferences, 150, 1-6. doi: 10.1051/matecconf/ $\underline{201815005097}$

Barthelemy, O. J., Richardson, M. A., Cabral, H. J., \& Frank, D. A. (2016). Prenatal, perinatal, and adolescent exposure to marijuana: Relationships with aggressive behaviour. Neurotoxicology and Teratology, 58, 60-77. doi: $\underline{10.1016 / j . n t t .2016 .06 .009}$

Bloom, M. (1996). Primary prevention practices (Issues in). California: Sage Publication.

BNN. (2015). Executive summary press release akhir tahun. Diunduh pada 20 Februari 2019 dari https:// id.scribd.com/document/330343882/Pr ess-Release-Akhir-Tahun-2015-Bnn

BNN, \& Puslitkes UI. (2015). Laporan akhir survei nasional perkembangan penyalahguna narkoba tahun anggaran 2014. Depok: BNN \& Puslitkes UI.

Caputo, A. (2019). The experience of therapeutic community: Emotional and motivational dynamics of people with drug addiction following rehabilitation. International Journal of Mental Health and Addiction, 17(1), 151165. doi: $\underline{10.1007 / s 11469-018-0008-4}$

Dayton, T. (2006). The set up: Living with addiction. Rockville, Maryland. Retrieved from https://www.tiandayton.com/wpcontent/uploads/2013/03/The-Set-Up- 
Living-With-Addiction.pdf

De Leon, G. (2000). The therapeutic community: Theory, model, and method. New York: Springer Publishing Company, Inc.

Dragisic, T., Dickov, A., Dickov, V., \& Mijatovic, V. (2015). Drug addiction as risk for suicide attempts. Materia SocioMedica, 27(3), 188-191. doi: 10.5455/ msm.2015.27.188-191

Elliott, T. R., \& Rath, J. F. (2011). Rehabilitation psychology. In E. M. Altmaier \& J.-I. C. Hansen (Eds.), The Oxford Handbook of Counseling Psychology (First). Oxford University Press.

doi:

10.1093/oxfordhb/9780195342314.013.0 $\underline{026}$

Fahrudin, A., \& Nurdin, D. (2010). Coping strategies and relapse of substance abusers: A case study of the therapeutic community program in Indonesia. Asian Social Work and Policy Review, 4(2), 98-117. doi: 10.1111/j.1753-1411.2010.00040.x

Fajriah, E., Husaini, \& Adenan. (2016). Pendekatan metode narcotics anonymous dalam pemulihan korban penyalahgunaan narkoba di Yayasan Lingkaran Harapan Banua Banjarmasin. Jurnal Berkala Kesehatan, 1(2), 96-106.

Flexon, J. L., Medrum, R. C., Young, J. T. N., \& Lehmann, P. S. (2016). Low selfcontrol and the dark triad: Disentangling the predictive power of personality traits on young adult substance use, offending and victimization. Journal of Criminal Justice, 46, 159-169. doi: $\underline{10.1016 / j . j c r i m j u s .2016 .05 .006}$

Fooladi, N., Jirdehi, R., \& MohtashamAmiri, Z. (2014). Comparison of depression, anxiety, stress and quality of life in drug abusers with normal subjects. Procedia Social and Behavioral Sciences, 159, 712-717. doi: 10.1016/j.sbspro.2014.12.459

Gordon, J. D., \& Gordon, D. D. (1999). Penggunaan - penyalahgunaan - adiksi N.A.Z.A dalam perspektif Psikologi. Makalah Sarasehan. Jakarta

Gossop, M., Stewart, D., \& Marsden, J. (2007). Attendance at narcotics anonymous and alcoholics anonymous meetings, frequency of attendance and substance use outcomes after residential treatment for drug dependence: A 5-year follow-up study. Addiction, 103, 119-125. doi: 10.1111/j.1360-0443.2007.02050.x

Gott, A. J., \& Hetzel-Riggin, M. D. (2018). What did you expect? Substance use expectancies mediate the relationships between dark triad traits, substance use, and substance preference. Psychological Reports, 121(5), 831-852. doi: $\underline{10.1177 / 0033294118755094}$

Hadži-Pešić, M., Mitrović, M., Car, K. B., \& Stojanović, D. (2014). Personality of alcohol addict according to the theory of transactional analysis. Procedia Social and Behavioral Sciences, 127, 230234. doi: $10.1016 /$ j.sbspro.2014.03.246

Hoseinifar, J., Zirak, S. R., Shaker, A., Meamar, E., Moharami, H., \& Siedkalan, M. M. (2011). Comparison of quality of life and mental health of addicts and non- addicts. Procedia Social and Behavioral Sciences, 30, 19301934. doi: $10.1016 /$ j.sbspro.2011.10.375

Ibrahim, F., Kumar, N., \& Samah, B. A. (2011). Self-efficacy and relapsed addiction tendency: An empirical study. The Social Sciences, 6(4), 277-282.

Jakubczyk, A., Trucco, E. M., Kopera, M., Kobyliński, P., Suszek, H., Fudalej, S., ... Wojnar, M. (2018). The association 
between impulsivity, emotion regulation, and symptoms of alcohol use disorder. Journal of Substance Abuse Treatment, 91, 49-56. doi: 10.1016/ j.jsat.2018.05.004

Järvinen, M. (2017). From wanting to willing - controlled drug use as a treatment goal. Social Science $\mathcal{E}$ Medicine, 176, 69-76. doi: 10.1016/ j.socscimed.2017.01.030

Johnson, K. W., Pan, Z., Young, L., Vanderhoff, J., Shamblen, S., Browne, T., ... Suresh, G. (2008). Therapeutic community drug treatment success in Peru: A follow-up outcome study. Substance Abuse: Treatment, Prevention, and Policy, 3(26), 1-15. doi: $\underline{10.1186 / 1747-597 X-3-26}$

Johnson, K. W., Young, L., Shamblen, S., Suresh, G., Browne, T., \& Chookhare, K. W. (2012). Evaluation of the therapeutic community treatment model in Thailand: Policy implications for compulsory and prison-based treatment. Substance Use $\mathcal{E}$ Misuse, 47(8-9), 889-909. doi: 10.3109/ $\underline{10826084.2012 .663279}$

Kadam, M., Sinha, A., Nimkar, S., Matcheswalla, Y., \& De Sousa, A. (2017). A comparative study of factors associated with relapse in alcohol dependence and opioid dependence. Indian Journal of Psychological Medicine, 39(5). doi: 10.4103/IJPSYM.IJPSYM 35617

Karow, A., Reimer, J., Schafer, I., Krausz, M., Haasen, C., \& Verthein, U. (2010). Quality of life under maintenance treatment with heroin versus methadone in patients with opioid dependence. Drug and Alcohol Dependence, 112, 209-215. doi: 10.1016/j.drugalcdep.2010.06.009

Kassel, J. D., Weinstein, S., Skitch, S. A.,
Veilleux, J., \& Mermelstein, R. (2005). The Development of Substance Abuse in Adolescence: Correlates, Causes and Consequences. In B. L. Hankin \& J. R. Z. Abela (Eds.), Development of psychopathology: A vulnerability-stress perspective (pp. 355-384). California: Sage Publication.

Kelly, T. H., \& Bardo, M. T. (2016). Emotion regulation and drug abuse: Implications for prevention and treatment. Drug and Alcohol Dependence, 163(Suppl. 1), S1-S2. doi: 10.1016/j.drugalcdep.2016.02.038

Kipper, D., \& Whitney, S. (2010). The Addiction solution: Unraveling the mysteries of addiction cutting-edge brain science. New York: Rodale Inc.

Kusrohmaniah, S. (2004). Kinerja kognitif pada pengguna NAPZA (Narkotika, Psikotropika, dan Zat Adiktif lainnya) ditinjau dari lama menggunakan dan banyaknya jenis napza yang digunakan. Tesis (tidak dipublikasikan). Yogyakarta: Fakultas Psikologi Universitas Gadjah Mada.

Lai, H. M. X., Cleary, M., Sitharthan, T., \& Hunt, G. E. (2015). Prevalence of comorbid substance use, anxiety and mood disorders in epidemiological surveys, 1990-2014: A systematic review and meta-analysis. Drug and Alcohol Dependence, 154, 1-13.

Larimer, M. E., Palmer, R. S., \& Marlatt, G. A. (1999). Relapse prevention: An overview of Marlatt's cognitivebehavioral model. Alcohol Research and Health, 23(2), 151-160.

Lee, H., Shin, S.-K., \& Park, S.-Y. (2014). Effects of a therapeutic community on Korean substance abusers in prison. Journal of Social Service Research, 40, 481-490. doi: $\underline{10.1080 / 01488376.2014 .922401}$ 
Lu, L., Liu, Y., Zhu, W., Shi, J., Liu, Y., Ling, W., \& Kosten, T. R. (2009). Traditional medicine in the treatment of drug addiction. The American Journal of Drug and Alcohol Abuse, 35, 1-11. doi: $\underline{10.1080 / 00952990802455469}$

Malivert, M., Fatséas, M., Denis, C., Langlois, E., \& Auriacombe, M. (2012). Effectiveness of therapeutic communities: A systematic review. European Addiction Research, 18, 1-11. doi: $10.1159 / 000331007$

Moore, T. M., \& Stuart, G. M. (2005). A review of the literature on marijuana and interpersonal violence. Aggression and Violent Behavior, 10, 171-192. doi: 10.1016/j.avb.2003.10.002

National Institute on Drug Abuse. (2015). Research report series: Therapeutic communities. Retrieved from https://www.drugabuse.gov/publicati ons/research-reports/therapeuticcommunities/what-are-therapeuticcommunities

Newman, B. M., \& Newman, P. R. (2012). Life-span Development: A Psychosocial Approach. Canada: Wardswort Cengage Learning.

Northam, J. C., \& Magor-Blatch, L. E. (2016). Adolescent therapeutic community treatment - an Australian perspective. Therapeutic Communities: The International Journal of Therapeutic Communities, 37(4), 204-212. doi: 10.1108/TC-01-2016-0002

Orwat, J., Samet, J. H., Tompkins, C. P., Cheng, D. M., Dentato, M. P., \& Saitz, R. (2011). Factors associated with attendance in 12-step groups (Alcoholics Anonymous/Narcotics Anonymous) among adults with alcohol problems living with HIV/AIDS. Drug and Alcohol Dependence, 113, 165-171. doi:

\subsection{6/j.drugalcdep.2010.07.021}

Pillon, S. C., O'Brien, B., \& Chavez, K. A. P. (2005). The relationship between drugs use and risk behaviors in Brazillian university students. Rev Latino-Am Enfermagem, 13, 1169-1176.

Pourmovahed, Z., Yassini A., S. M., Dehghani, H., \& Askari, J. (2013). Factors responsible for addiction from the viewpoint of wives of addicts. In Procedia - Social and Behavioral Sciences (Vol. 84, pp. 719-722). Elsevier B.V. doi: 10.1016/j.sbspro.2013.06.633

Prangley, T., Pit, S. W., Rees, T., \& Nealon, J. (2018). Factors influencing early withdrawal from a drug and alcohol treatment program and client perceptions of successful recovery and employment: A qualitative study. BMC Psychiatry, 18(301), 1-11. doi: 10.1186/s12888-018-1864-y

Prianto, P. H. (2007). Penerapan pendekatan therapeutic community terhadap korban penyalahgunaan NAPZA di PSPP "Sehat Mandiri" Yogyakarta. Tesis (tidak dipublikasikan). Yogyakarta: Fakultas Ilmu Sosial dan Politik Universitas Gadjah Mada.

Primadi, O. (2014). Gambaran umum penyalahgunaan narkoba. Buletin Jendela Data dan Informasi Kesehatan, Semester 1.

Purwandari, E. (2015). Model kontrol sosial perilaku remaja bersisiko penyalahgunaan NAPZA. Disertasi (tidak dipublikasikan). Yogyakarta: Fakultas Psikologi Universitas Gadjah Mada.

Raesei, A., Sarani, H., Arbabisarjou, A., \& Mojahed, A. (2015). The most common reasons and incentives of tendency to addiction in prisons and rehabilitation centres of Zahedan (Iran). Global Journal of Health Science, 7(4), 329-334.

Rafaiee, R., Olyaee, S., \& Sargolzaiee, A. 
(2013). The relationship between the type of crime and drugs in addicted prisoners in Zahedan Central Prison. International Journal of High Risk Behaviors and Addiction, 2(3), 139-140. doi: $10.5812 /$ ijhrba. 13977

Rath, J. F., \& Elliott, T. R. (2012). Psychological models in rehabilitation psychology. In P. Kennedy (Ed.), The oxford handbook of rehabilitation psychology (First). Oxford University Press. doi: 10.1093/oxfordhb/9780199733989.013.0 $\underline{003}$

Ritchwood, T. D., DeCoster, J., Metzger, I. W., Bolland, J. M., \& Danielson, C. K. (2016). Does it really matter which drug you choose? An examination of the influence of type of drug on type of risky sexual behavior. Addictive Behaviors, 60, 97-102. doi: 10.1016/j.addbeh.2016.03.022

Rostami, R., Zarei, J., Zamiri, S., \& Larijani, R. (2010). Childhood abuse history among male addicts in comparison with non-addict population. ProcediaSocial and Behavioral Sciences, 5, 738-740. doi: 10.1016/j.sbspro.2010.07.175

Rusnáková, M. (2014). Codependency of the members of a family of an alcohol addict. Procedia-Social and Behavioral Sciences, 132, 647-653. doi: 10.1016/j.sbspro.2014.04.367

Rutherford, H. J. V, \& Mayes, L. C. (2017). Parenting and addiction: Neurobiological insights. Current Opinion in Psychology, 15, 55-60. doi: 10.1016/j.copsyc.2017.02.014

Santrock, J. W. (2016). A topical approach to life-span development (7th ed.). New York: McGraw-Hill.

Sarasvita, R., \& Raharjo, B. (2014). Program wajib lapor pecandu narkotika. Buletin Jendela Data Dan Informasi Kesehatan
Kemenkes RI, 29-41.

Sharifi, H., Kharaghani, R., Sigari, S., Emami, H., Sadr, M., \& Masjedi, M. R. (2012). Common methods to treat addiction in treatment-rehabilitation centers in Tehran. Iranian Journal of Public Health, 41(4), 63-68.

Smith, J. M., \& Estefan, A. (2014). Families parenting adolescence with substance abuse-recovering the mother's voice: A narative literature review. Journal of Family Nursing, 20(4), 415-441.

Smith, P. H., Homish, G. G., Leonard, K. E., \& Collins, R. L. (2013). Marijuana withdrawal and aggression among a representative sample of U.S. marijuana users. Drug and Alcohol Dependence, 132, 63-68. doi: 10.1016/j.drugalcdep.2013.01.002

Sofuoglu, M., DeVito, E. E., Waters, A. J., \& Carroll, K. M. (2013). Cognitive enhancement as a treatment for drug addictions. Neuropharmacology, 64, 452463.

doi:

10.1016/j.neuropharm.2012.06.021

Solinas, M., Thiriet, N., Chauvet, C., \& Jaber, M. (2010). Prevention and treatment of drug addiction by environmental enrichment. Progress in Neurobiology, 92, 572-592. doi: 10.1016/j.pneurobio.2010.08.002

Soyez, V. (2004). The influence of social networks on retention in and success after therapeutic community treatment. Orthopedagogissche Reeks Gent, 16.

Steinberg, L. (2011). Adolescence (9th ed.). New York: McGraw-Hill.

Sumantri, A. (2017). Baru 16 ribu pecandu narkoba direhabilitasi sepanjang tahun ini. Retrieved February 2, 2019, from https://mediaindonesia.com/read/deta il/123380-baru-16-ribu-pecandunarkoba-direhabilitasi-sepanjang- 
tahun-ini

Vanderplasschen, W., Colpaert, K., Autrique, M., Rapp, R. C., Pearce, S., Broekaert, E., \& Vandevelde, S. (2013). Therapeutic communities for addictions: A review of their effectiveness from a recovery-oriented perspective. The Scientific World Journal, 2013, 1-22. doi: $\underline{10.1155 / 2013 / 427817}$

Wayman, C. (2013). Group versus individual therapy in adolescent substance abuse treatment: Finding interventions that work. Counselor Education Master's Theses. 152.

Whitesell, M., Bachand, A., Peel, J., \& Brown, M. (2013). Familial, social, and individual factors contributing to risk for adolescent substance use. Journal of Addiction, 2013, 1-9. doi: $\underline{10.1155 / 2013 / 579310}$

Wingo, A. P., Ressler, K. J., \& Bradley, B. (2014). Resilience characteristics mitigate tendency for harmful alcohol and illicit drug use in adults with a history of childhood abuse: A crosssectional study of 2024 inner-city men and women. Journal of Psychiatric Research, 51, 93-99.

Zamani, Z. A., Nasir, R., Desa, A., Khairudin, R., \& Yusooff, F. (2014). Family functioning, cognitive distortion and resilience among clients under treatment in drug rehabilitation centres in Malaysia. Procedia - Social and Behavioral Sciences, 2, 150-154. doi: 10.1016/j.sbspro.2014.04.401

Zhu, W., Zhang, Y., Huang, Y., \& Lu, L. (2017). Chinese herbal medicine for the treatment of drug addiction. International Review of Neurobiology, 135, 279-295. doi: 10.1016/bs.irn.2017.02.013

Zilberman, N., Yadid, G., Efrati, Y., Neumark, Y., \& Rassovsky, Y. (2018). Personality profiles of substance and behavioral addictions. Addictive Behaviors, 82, 174-181. doi: 10.1016/j.addbeh.2018.03.007 